\title{
BEBERAPA PENCIRI BERBASIS SEKUENS UNTUK MENGENALI SIFAT FUNGSIONAL PEPTIDA BIOAKTIF: STUDI EKSPLORASI
}

\author{
[Sequence-based Identifiers to Recognize the Functionality of \\ Bioactive Peptides: An Explorative Study]
}

\author{
Badrut Tamam¹, Dahrul Syah ${ }^{2)}$, Hanifah Nuryani Lioe ${ }^{2)}$, Maggy T. Suhartono ${ }^{2) \star,}$ \\ dan Wisnu Ananta Kusuma ${ }^{3)}$ \\ 1) Program Studi IImu Pangan, Sekolah Pascasarjana, Institut Pertanian Bogor, Bogor \\ 2) Departemen IImu dan Teknologi Pangan, Fakultas Teknologi Pertanian, Institut Pertanian Bogor, Bogor \\ ${ }^{3)}$ Departemen IImu Komputer, Fakultas Matematika dan IImu Pengetahuan Alam, Institut Pertanian Bogor, Bogor
}

Diterima 13 Juni 2017 / Dis etujui 05 Maret 2018

\begin{abstract}
Bioactive peptides have important roles as functional food ingredients. The sequence patterns of amino acids in a peptide fragment may relate to their functional mechanisms. On the contrary, presence of an amino acid in a peptide fragment might not be sufficient to provide a unique identifier toward the bioactive peptide functional properties such as antihypertensive $(A H)$, antioxidative $(A O)$ or antimicrobial (AM). The main objective of this study was to explore the identifiers of bioactive peptides based on the sequence-generated properties. This study was performed using meta-analysis by utilizing many data sources and qualified international journal publications. The identifiers of bioactive peptides include sequence length, molecular weight, isoelectric point (pl), net charge and hydrophobicity. Based on the average score of the five identifiers, antimicrobial (AM) peptides were very different from antihypertensive $(A H)$ and antioxidative $(A O)$ peptides. The comparisons of the peptide biofunctional properties based on the identifiers may be determined as follows: $A H 1<A O 1<A M 1$ (for sequence length); $A H 1<A O 1<A M 1$ (for molecular weight); $A H 1=A O 1<A M 1$ (for isoelectric point/pl); $A H 1=A O 1<A M 1$ (for net charge) and $A H 1<A M 1<A O 1$ (for hydrophobicity).
\end{abstract}

Keywords: amino acid sequences, antihypertensive peptides, antioxidative peptides, antimicrobial peptides, functional foods

\begin{abstract}
ABSTRAK
Peptida bioaktif memiliki peran penting sebagai bahan pangan fungsional. Pola sekuens asam amino dalam fragmen peptida diduga terkait dengan mekanisme fungsional dari peptida-petida tersebut. Kehadiran suatu asam amino di dalam fragmen peptida tidaklah cukup untuk memberikan penciri unik terhadap suatu sifat fungsional peptida bioaktif seperti peran sebagai antihipertensi $(A H)$, antioksidan $(A O)$ dan antimikroba (AM). Tujuan dari penelitian ini adalah mengeksplorasi penciri peptida bioaktif berdasarkan beberapa sifat yang dibangkitkan dari sekuensnya. Penelitian ini dilakukan secara meta-analysis dengan memanfaatkan berbagai sumber data dan publikasi berbagai jurnal ilmiah internasional yang berkualitas. Penciri peptida bioaktif meliputi panjang sekuen, berat molekul, titik isoelektrik (pl), muatan bers ih (net charge) dan hidrofobisitas. Berdasarkan nilai rerata terhadap kelima penciri ters ebut, peptida anti mikroba memiliki perbedaan cukup besar dengan peptida antihipertensi dan antioksidan. Perbandingan sifat fungsional peptida didasarkan atas penciri-penciri tersebut dapat ditentukan sebagai berikut yaitu $\mathrm{AH} 1<\mathrm{AO} 1<\mathrm{AM} 1$ (untuk panjang sekuen); $\mathrm{AH} 1<\mathrm{AO} 1<\mathrm{AM} 1$ (untuk berat molekul); $\mathrm{AH} 1=\mathrm{AO} 1<\mathrm{AM} 1$ (untuk titik is oelektrik); $\mathrm{AH} 1=\mathrm{AO} 1<\mathrm{AM} 1$ (untuk muatan bersih); dan $\mathrm{AH} 1<\mathrm{AO} 1>\mathrm{AM} 1$ (untuk hidrofobisitas).
\end{abstract}

Kata kunci: pangan fungsional, peptida antihipertensi, peptida antioksidan, peptida antimikroba, sekuens asam amino

\section{PENDAHULUAN}

Dalam dekade terakhir ini, peptida yang memiliki khasiat kesehatan tertentu telah menjadi tema penelitian dan sorotan menarik. Beberapa penelitian telah mengungkap bahwa fragmen protein dalam

${ }^{*}$ Penulis Korespondensi:

E-mail: mthenawidjaja@yahoo.com bentuk peptida memiliki peran sebagai pangan fungsional. Peran fungsional dari peptide bioaktif diantaranya sebagai antihipertensi, antioksidan, antimikroba, antitrombotik, antiadipogenik (antiobesitas), antikanker, aktifitas opioid, antihiperkolesterol, immunomodulator dan antidiabet (kencing manis) (Abdelhadi et al., 2017; Capriotti et al., 2015). Peptida bioaktif umumnya terikat di dalam sekuen asam 
amino suatu protein bahan pangan yang terdiri atas 2 sampai 20 asam amino, meskipun ada juga yang melaporkan lebih dari 20 asam amino (Ryan et al., 2011). Pola sekuen asam amino dalam fragmen peptida tersebut diduga terkait dengan mekanisme fungsional dari peptida-petida tersebut. Kehadiran asam amino dengan gugus aromatik dan alifatik, seperti Pro $(P)$, Phe $(F)$ atau Tyr $(Y)$ pada atom $C$ terminal serta $\mathrm{Val}(\mathrm{V})$ dan Ile (I) pada posisi atom $\mathrm{N}$ terminal diduga terkait dengan angiotensin 1-converting enzyme (ACE) inhibitor atau anti hipertensi (Wijesekara et al., 2011). Disamping itu, asam amino yang memiliki karakter hidrofobik seperti Try $(Y)$, Phe (F), Trp (W), Ala (A), lle (I), Val (V), dan Met (M) serta asam amino bermuatan positif seperti $\operatorname{Arg}(\mathrm{R})$ dan Lys (K) menunjukkan afinitas yang baik dengan ACE (He et al., 2012; Rai et al., 2015). Peran peptida bioaktif sebagai antioksidan diduga karena kehadiran asam amino Tyr $(\mathrm{Y})$, Trp $(\mathrm{W})$, Met $(\mathrm{M})$, Lys $(\mathrm{K})$ dan Cys (C) yang memiliki kemampuan mereduksi ion $\mathrm{Fe} 3+$ menjadi $\mathrm{Fe} \mathrm{2+}$ dan mengikat (chelate) ion Fe 2+ and $\mathrm{Cu} 2+$ (Carrasco-Castilla et al., 2012; Huang et al., 2010). Sedangkan asam amino aromatik yang memiliki gugus fenol, indol dan imidazole seperti Trp, Tyr, Phe, His dapat berperan sebagai donor elektron dan secara efisien menangkap senyawa radikal (Duan et al., 2014; Sarmadi dan Ismail, 2010).

Peran antimikroba dari peptida bioaktif diduga karena karakter hidrofobisitas dari peptida tersebut. Peptida yang memiliki hidrofobisitas tinggi mengandung sekuen asam amino yang kaya akan Gly (G) dan Leu (L). Sedangkan kehadiran residu asam amino $\operatorname{Arg}(R)$ yang memiliki gugus kation dilaporkan memainkan peran penting sebagai antimikroba karena dapat berinteraksi dengan dinding sel bakteri (Amadou et al., 2013; Tang et al., 2015). Meskipun demikian, Dashper et al. (2007) menyatakan bahwa mekanisme aksi dari peptida antimikroba belum jelas mengingat demikian banyak jumlah antimikroba yang telah ditemukan. Terlihat dari uraian di atas, alasan kehadiran suatu asam amino tidaklah cukup untuk memberikan penciri unik terhadap suatu sifat fungsional. Analisis harus dilakukan berdasarkan penciri yang berlandaskan urutan-urutan asam amino (sekuens). Berdasarkan latar belakang tersebut di atas, tujuan penelitian ini adalah mengeksplorasi penciri peptida bioaktif yang memiliki sifat fungsional sebagai antihipertensi $(A H)$, antioksidan $(A O)$, dan antimikroba (AM) berdasarkan beberapa sifat yang dibangkitkan dari sekuensnya.

\section{BAHAN DAN METODE}

\section{Bahan}

Bahan yang digunakan dalam penelitian ini berupa sumber data sekunder dan publikasi ber- bagai jurnal ilmiah internasional yang berkualitas yang dianalisis secara meta-analysis. Sumber data dan publikasi internasional tersebut digunakan untuk penyusunan pustaka peptida bioaktif dan pembangkitan penciri berdasarkan sekuens dari peptida bioaktif tersebut

\section{Penyusunan pustaka peptida bioaktif}

Penyusunan pustaka peptida bioaktif dilakukan dengan penelusuran sekuen asam amino peptida bioaktif dari jurnal-jurnal ilmiah internasional yang berkualitas (setidaknya memiliki impact factor 1, diakui oleh komunitas ilmiah atau terindeksi Scopus/Thomson atau memiliki tingkat sitasi yang tinggi menurut komunitas Open Source Researchgate. Sekuen asam amino peptida bioaktif tersebut kemudian ditabulasikan menjadi suatu pustaka peptida bioaktif, yang memuat nama peptida, sumber protein, penulis dan jurnal yang menerbitkan, dan dikategorikan berdasarkan sifat fungsional yang dilaporkan yaitu antihipertensi, antioksidan, atau antimikroba.

\section{Perhitungan penciri sifat berdasarkan sekuen peptida bioaktif}

Penciri yang dihitung dengan berdasarkan kepada sekuens asam amino peptida adalah panjang, berat molekul, titik isoelektrik (pl), muatan bersih (net charge) dan hidrofobisitas. Panjang sekuens menunjukkan jumlah residu asam amino dari suatu peptida bioaktif, berat molekul dihitung berdasarkan total berat atom semua residu asam amino penyusunnya, titik isoelektrik adalah $\mathrm{pH}$ saat muatan bersih peptida bioaktif adalah nol, muatan bersih dihitung berdasarkan jumlah residu yang bermuatan positif dan negatif pada $\mathrm{pH}$ netral dan hidrofobisitas diukur sebagai energi bebas untuk mengantarkan suatu peptida dari kondisi aqueous ke lingkungan hidrofobik yang ditetapkan dengan menggunakan skala Wimley-White dengan satuan $\mathrm{kcal} / \mathrm{mol}$. Perhitungan dilakukan dengan menggunakan program aplikasi PepDraw (Estrada, 2011).

\section{Klastering peptida bioaktif}

Pengelompokan penciri peptida bioaktif berdasarkan sifat fungsionalnya dianalisis dengan klaster analysis menggunakan aplikasi WEKA 3.9 data mining, dan dilanjutkan dengan biplot menggunakan aplikasi SAS 9.4. Sifat fisikokimia dari masing-masing peptida bioaktif dikelompokkan ke dalam tiga dan empat klaster, dimana klaster pertama menunjukkan jumlah anggota klaster terbanyak dan klaster berikutnya memiliki anggota lebih kecil. Nilai centroid masing-masing klaster diperoleh dari rerata nilai setiap anggota peptida bioaktif pada penciri tertentu di tiap klaster. Klaster dari masingmasing sifat fisikokimia, kemudian digambarkan dalam biplot dua dimensi dengan menggunakan aplikasi SAS 9.4. 


\section{HASIL DAN PEMBAHASAN}

\section{Pustaka peptida bioaktif}

Penelusuran peptida bioaktif pada jurnal-jurnal ilmiah internasional menghasilkan pustaka peptida bioaktif, yang dikelompokkan berdasarkan peran fungsionalnya di dalam tubuh. Secara keseluruhan rekap peptida bioaktif disajikan pada Tabel 1 .

Dari beberapa jurnal ilmiah internasional yang ditelusur, tiga sifat fungsional yang dominan pada peptida bioaktif adalah antihipertensi, antioksidan dan antimikroba, masing-masing 143 (8 peptida di antaranya berasal lebih dari satu asal bahan), 22 dan 25 peptida (Tabel 1). Sebagian besar peptida bioaktif tersebut berasal dari kedelai, diikuti susu dan gandum. Beberapa peptida bioaktif antihipertensi yang tertelusur di antaranya adalah YLAGNQ, IPPGVPYWT, ASYDTKF, DTKF, PNNKPFQ, dan DQTPRVF (Capriotti et al., 2015), YPYY (Tsai et al., 2008), VPP, IPP, GY, AF, VP, Al, dan VG (Castro dan Sato, 2015), AW, AY, GW dan SY (Sanjukta dan Rai, 2015), EVSLNSGYY, PGTAVFK dan VH LPP (McClean et al., 2014), RPKHPIKHQG LPQEV, EVLNENLLRF, FVAPFPEVFGK, YQEPVLGPVRG PF, YQEPVLGPVRGPFPI dan YQEPVLGPVRGPF PIIV (Torres-Llanez et al., 2011), APAMR, EAPRY, IPSEVLS, KHFLA, NSGPLVNP dan RPSYTNGPQ EIYIQQGKGIFG (Puchalska et al., 2014). Demikian juga peptida bioaktif antioksidan diantaranya adalah LLPHHADADY, LLPHH, LVNPH DHQN, TTYY dan LQSGDALRVPSGTTY (Capriotti et al., 2015), QSGDALR dan RPSYT (Puchalska et al., 2014), IRHFNEGDVLVIPPGVPY, IRHFNEGDVLVIPPGVP YW, YRAELSEQDIFVIPAG, IYNFREGDLIA VPTG dan VSIIDTNSLENQLDQMPRR (Coscueta et al., 2015). Sedangkan peptida bioaktif antimikroba di antaranya adalah IIVVQGKGAIGF, ASRGIRVNG VAPGPVWTPIQPA, IIIAQGKGALGV, IVTVKGGLR VTAPA, LFVLSGRAIL, KIGGIGTVPVGRVETGVLK PGMVV, SGGIKLPTDIISKISPLPVLKEI dan LAFPG SAKDIENLIKSQ (Capriotti et al., 2015), GLSRLFTA LK (Castro dan Sato, 2015), PGTAVFK dan TTMP LW (McClean et al., 2014).

Bioactive peptide (BIOPEP) database yang dikembangkan oleh University of Warmia dan Mazury di Polandia melaporkan memiliki 3389 peptida bioaktif (Minkiewicz et al., 2008). Di dalam BIOPEP database, jumlah peptida antihipertensi sebanyak 799, peptida antimikroba 464 dan peptida antioksidan 539. Jika dibandingkan hasil penelusuran peptida bioaktif dari jurnal ilmiah internasional masih sangat kecil dibandingkan keberadaan peptida bioaktif di database BIOPEP, yang mana peptida antihipertensi baru tergali $17,9 \%$, anti-mikroba $5,4 \%$ dan antioksidan $4,1 \%$.

\section{Penciri peptida bioaktif berdasarkan sekuens asam amino}

Statistik dari penciri yang dibangkitkan dari sekuens asam amino dihubungkan dengan sifat fungsional yang dimilikinya disajikan pada Tabel 2 .

Peptida antihipertensi dan antioksidan memiliki nilai rerata yang hampir sama pada beberapa penciri seperti panjang sekuens, berat molekul, titik isoelektrik dan hidrofobisitas. Rerata panjang sekuen peptida antihipertensi dan antioksidan berada pada kisaran 7-8 residu asam amino, berat molekul berkisar 800-900 Da, titik isoelektrik berada pada kisaran 6-7, muatan bersih berada pada kisaran 0 , dan hidrofobisitas pada kisaran $10-11 \mathrm{kcal} / \mathrm{mol}$. Hal ini sejalan dengan apa yang dinyatakan Nagpal et al. (2011) bahwa peptida bioaktif antihipertensi yang memiliki residu asam amino pendek memiliki kemampuan yang lebih potensial untuk menghambat aktifitas angiotensin 1-converting enzyme (ACE). He et al. (2012) dan Rai et al. (2015) juga mengatakan bahwa beberapa peptida antihipertensi memiliki asam amino hidrofobik, asam amino bergugus aromatik dan alifatik dan bermuatan positif. Demikian juga Duan et al. (2014) mengungkap bahwa beberapa peptida yang berperan sebagai antioksidan memiliki residu asam amino aromatik yang memiliki gugus fenol, indol dan imidazole seperti Trp, Tyr, Phe, His dapat berperan sebagai donor elektron bagi senyawa radikal.

Peptida antimikroba memiliki perbedaan dengan peptida antihipertensi dan antioksidan berdasarkan kelima penciri tersebut yaitu panjang sekuens, berat molekul, titik isoelektrik, muatan bersih dan hidrofobisitas. Rerata panjang sekuens dan berat molekul peptida antimikroba $(14,8$ dan 1535,3$)$ hampir dua kali lebih besar dari peptida antihipertensi dan antioksidan (masing-masing 7,7 dan 8,4 serta 881,4 dan 965,9$)$. Rerata titik isoelektrik peptida antimikroba $(9,9)$ satu setengah kali peptida antihipertensi dan antioksidan (masing-masing 6,9 dan 6,1). Rerata muatan bersih peptida antihipertensi dan antioksidan berada pada kisaran 0 , sedangkan rerata muatan bersih peptida antimikroba di atas 1 .

Hidrofobisitas peptida antihipertensi dan antioksidan berada sekitar 10 dan 11, sedangkan peptida antimikroba hampir menembus angka 13 . Sebagaimana yang diungkap Amadou et al. (2013) bahwa kehadiran residu Arg (asam amino kationik) di dalam sekuens peptida berperan penting dalam aktivitas antimikroba, yang dapat meningkatkan interaksi dengan dinding sel bakteri. 
Tabel 1. Jumlah peptida bioaktif dari berbagai bahan yang diperoleh dari hasil-hasil penelitian dalam jurnal ilmiah internasional

\begin{tabular}{|c|c|c|c|c|c|c|c|}
\hline \multirow{2}{*}{ No } & \multirow{2}{*}{ Asal Bahan } & \multicolumn{6}{|c|}{ Jumlah Peptida Bioaktif } \\
\hline & & Anti Hipertensi & $\%$ & Anti Oksidan & $\%$ & Anti Mikroba & $\%$ \\
\hline 1 & Kedelai & 70 & 48,9 & 19 & 86,5 & 23 & 92,0 \\
\hline 2 & Susu & 53 & 37,1 & 1 & 4,5 & 1 & 4,0 \\
\hline 3 & Beras & 2 & 1,4 & - & & - & \\
\hline 4 & Gandum & 9 & 6,3 & - & & - & \\
\hline 5 & Gelatin dan jaringan otot & 2 & 1,4 & 2 & 9,0 & - & \\
\hline 6 & Barley & 1 & 0,7 & - & & - & \\
\hline 7 & Jagung & 5 & 3,5 & - & & - & \\
\hline 8 & Bunga matahari & 1 & 0,7 & - & & - & \\
\hline 9 & Anchovies & - & & - & & 1 & 4,0 \\
\hline & Total & 143 & 100 & 22 & 100 & 25 & 100 \\
\hline
\end{tabular}

Keterangan: Prosentase jumlah peptida bioaktif dihitung untuk masing-masing sifat fungsional; Sumber: ${ }^{1}$ Capriotti et al., 2015;

${ }^{2}$ Tsai et al., 2008; ${ }^{3}$ Castro dan Sato, 2015; ${ }^{4}$ Sanjukta dan Rai, 2015; ${ }^{5}$ McClean et al., 2014; ${ }^{6}$ Puchalska et al., 2014;

${ }^{7}$ Coscueta et al., 2015

Tabel 2. Statistik penciri berbasis sekuens peptida bioaktif dan sifat fungsionalnya

\begin{tabular}{|c|c|c|c|c|}
\hline Penciri & Statistik & Antihipertensi & Antioksidan & Antimikroba \\
\hline $\begin{array}{l}\text { Panjang } \\
\text { Sekuens }\end{array}$ & $\begin{array}{l}\text { Minimum } \\
\text { Quartil 1 } \\
\text { Median } \\
\text { Quartil 3 } \\
\text { Maksimum } \\
\text { Rata-rata }\end{array}$ & $\begin{array}{c}2 \\
3 \\
6 \\
10 \\
30 \\
7,67 \pm 5,5^{\mathrm{a}}\end{array}$ & $\begin{array}{c}2 \\
4 \\
6,5 \\
15 \\
19 \\
8,4 \pm 5,9^{a}\end{array}$ & $\begin{array}{c}6 \\
11 \\
14 \\
19 \\
24 \\
14,8 \pm 4,8^{\circ}\end{array}$ \\
\hline Berat Molekul & $\begin{array}{l}\text { Minimum } \\
\text { Quartil 1 } \\
\text { Median } \\
\text { Quartil 3 } \\
\text { Maksimum } \\
\text { Rata-rata }\end{array}$ & $\begin{array}{c}174,1 \\
391,2 \\
718,4 \\
1131,6 \\
3243,6 \\
881,4 \pm 615,2^{a}\end{array}$ & $\begin{array}{c}226,1 \\
546,2 \\
730,4 \\
1663 \\
2228 \\
965,9 \pm 665,3^{\mathrm{a}}\end{array}$ & $\begin{array}{c}718,4 \\
1130,2 \\
1428,8 \\
1931,1 \\
2417,4 \\
1535,3 \pm 490,9^{\circ}\end{array}$ \\
\hline Titik Isoelektrik & $\begin{array}{l}\text { Minimum } \\
\text { Quartil 1 } \\
\text { Median } \\
\text { Quartil 3 } \\
\text { Maksimum } \\
\text { Rata-rata }\end{array}$ & $\begin{array}{c}3,02 \\
5,4 \\
5,6 \\
9,5 \\
11,7 \\
6,9 \pm 2,3^{a}\end{array}$ & $\begin{array}{c}3,1 \\
5,2 \\
5,5 \\
6,5 \\
11,5 \\
6,1 \pm 1,9^{a}\end{array}$ & $\begin{array}{c}5,2 \\
9,9 \\
10,2 \\
11,2 \\
12,5 \\
9,9 \pm 1,9^{\circ}\end{array}$ \\
\hline Muatan Bersih & $\begin{array}{l}\text { Minimum } \\
\text { Quartil 1 } \\
\text { Median } \\
\text { Quartil 3 } \\
\text { Maksimum } \\
\text { Rata-rata }\end{array}$ & $\begin{array}{c}-2 \\
0 \\
0 \\
1 \\
3 \\
0,2 \pm 0,9^{\mathrm{a}}\end{array}$ & $\begin{array}{c}-2 \\
-1 \\
0 \\
0 \\
2 \\
-0,3 \pm 0,9^{\circ}\end{array}$ & $\begin{array}{c}-1 \\
1 \\
1 \\
2 \\
4 \\
1,2 \pm 1^{\mathrm{c}}\end{array}$ \\
\hline Hidrofobisitas & $\begin{array}{l}\text { Minimum } \\
\text { Quartil 1 } \\
\text { Median } \\
\text { Quartil 3 } \\
\text { Maksimum } \\
\text { Rata-rata }\end{array}$ & $\begin{array}{c}3,2 \\
6,9 \\
9 \\
12,2 \\
27,3 \\
10,1 \pm 4,5^{\mathrm{a}}\end{array}$ & $\begin{array}{c}4,5 \\
7,5 \\
12,6 \\
15,6 \\
21.1 \\
11,1 \pm 4,0^{\text {ab }}\end{array}$ & $\begin{array}{c}4,5 \\
9,4 \\
10,9 \\
16,9 \\
24,9 \\
12,6 \pm 5,2^{D}\end{array}$ \\
\hline
\end{tabular}

Keterangan: Huruf yang berbeda pada setiap penciri menunjukkan perbedaan nyata pada taraf uji $P \leq 0,05$

Hal itu disebabkan sel bakteri kaya akan fosfolipid bermuatan negatif menghadap ke lingkungan luar, sehingga memudahkan berinteraksi dengan peptida yang bermuatan positif. Meskipun demikian, hidrofobisitas dari peptida yang mengandung Gly dan Leu dilaporkan juga sebagai molekul antimikroba yang potensial. Kesulitan untuk mendapatkan penciri dengan hanya berlandaskan kepada sifat tunggal juga terlihat di dalam diagram pencar sifatsifat tersebut sebagaimana disajikan pada Gambar 1a, 1b, 1c, 1d, dan 1e. Terlihat dari diagram pencar (Gambar 1a, 1b, 1c, 1d dan 1e), belum memungkinkan untuk menarik penciri sifat fungsional peptida dengan hanya mengandalkan satu penciri tunggal. 


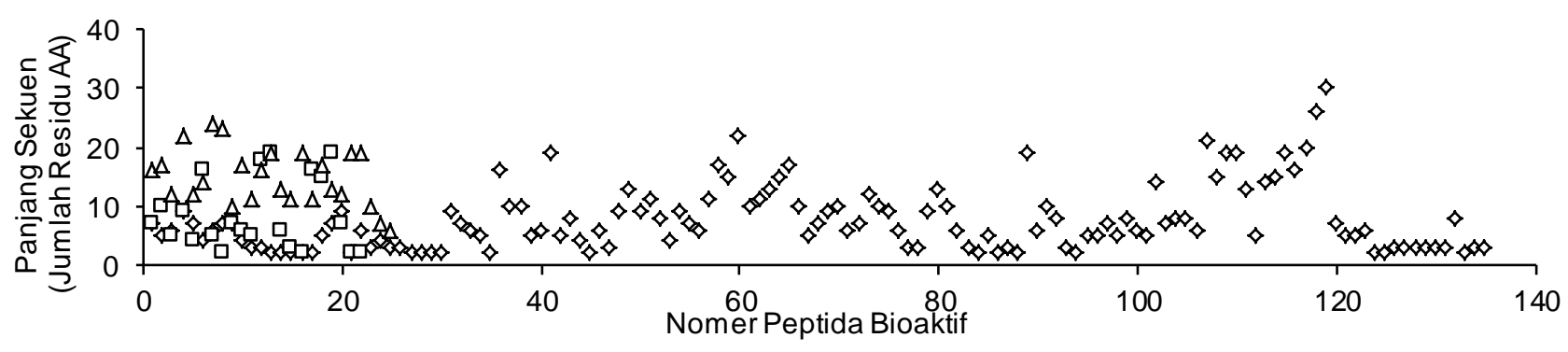

$\diamond$ antihipertensi $\square$ antioksidan $\Delta$ antimikroba

Gambar 1a. Distribusi peptida bioaktif berdasarkan panjang sekuens

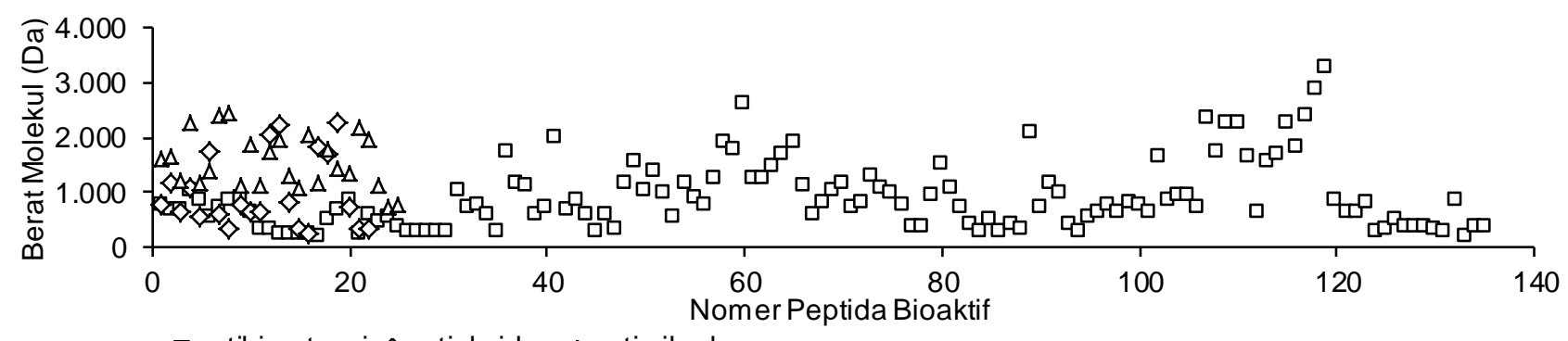

口antihipertensi $\diamond$ antioksidan $\Delta$ antimikroba

Gambar 1b. Distribusi peptida bioaktif berdasarkan berat molekul

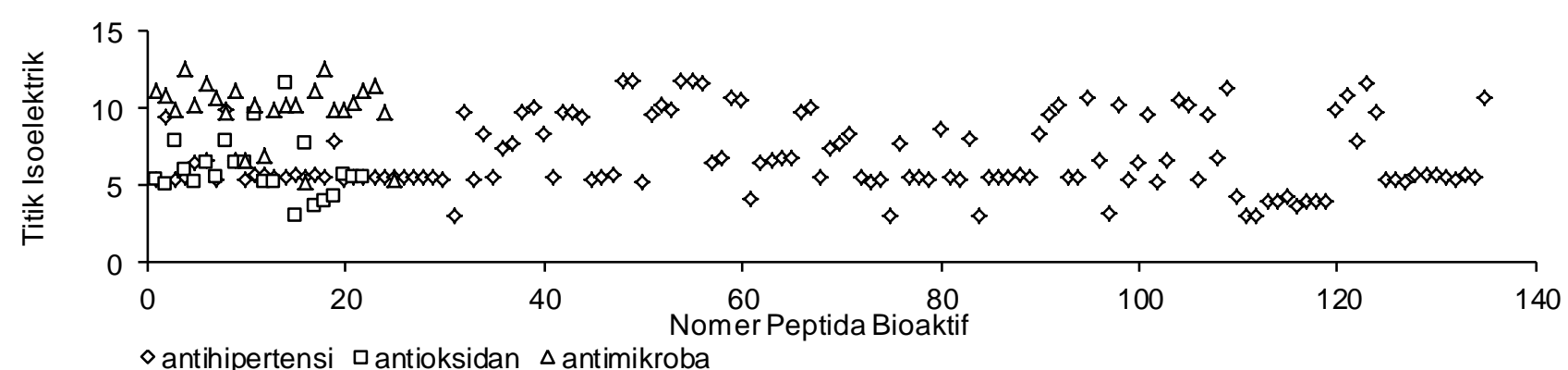

$\diamond$ antihipertensi $\square$ antioksidan $\Delta$ antimikroba

Gambar 1c. Distribusi peptida bioaktif berdasarkan titik isoelektrik

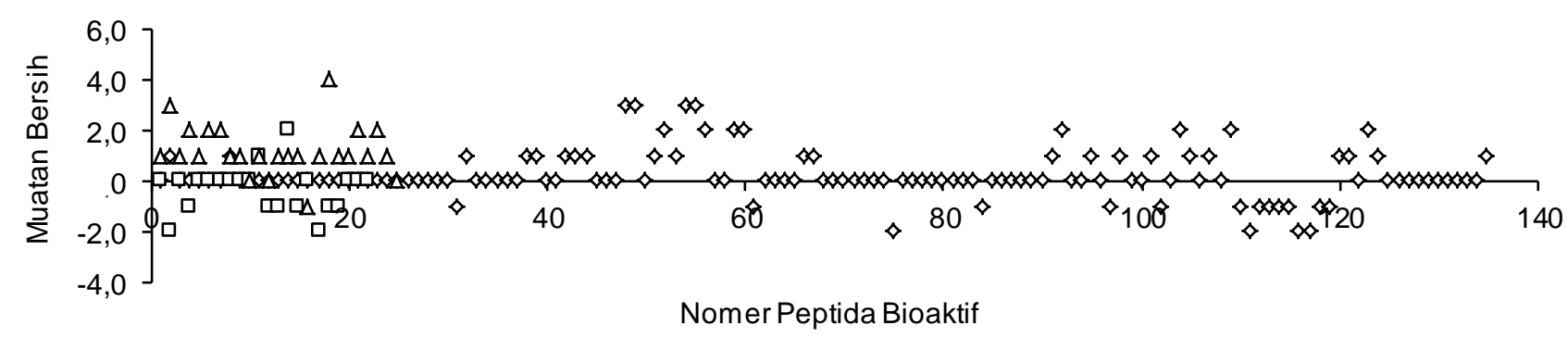

$\diamond$ antihipertensi $\square$ antioksidan $\Delta$ antimikroba

Gambar 1d. Distribusi peptida bioaktif berdasarkan muatan bersih

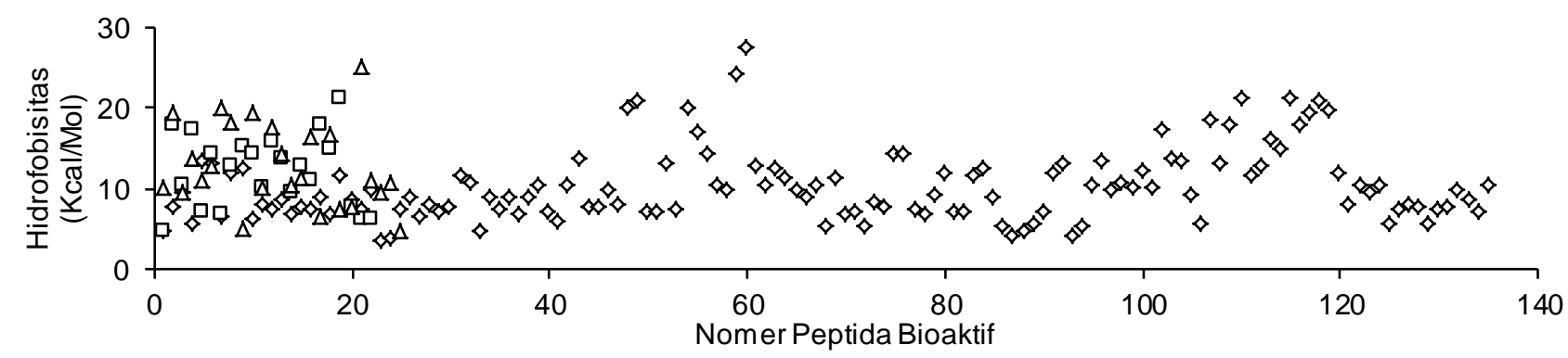

$\diamond$ antihipertensi $\square$ antioksidan $\Delta$ antimikroba

Gambar 1e. Distribusi peptida bioaktif berdasarkan hidrofobisitasnya 
Mengingat sulitnya mendapatkan penciri dengan hanya menggunakan satu penciri tunggal yang diturunkan dari sekuens, maka dilakukan analisis biplot dengan menggunakan semua penciri secara simultan sebagaimana akan dibahas pada bagian berikut ini.

\section{Pengklasteran penciri dengan sifat fungsional peptida bioaktif}

Pengklasteran dilakukan dengan menggunakan dua strategi yaitu 4 dan 3 buah klaster. Hasil pengklasteran dengan menggunakan teknik biplot disajikan pada Gambar 2a dan 2b berikut ini. Biplotting dengan 4 klaster (Gambar 2a) dan 3 klaster (Gambar 2b) menunjukkan tidak ada plot klaster yang tumpang tindih. Kesemua plot klaster tersebar merata pada kuadran 1 hingga 4.

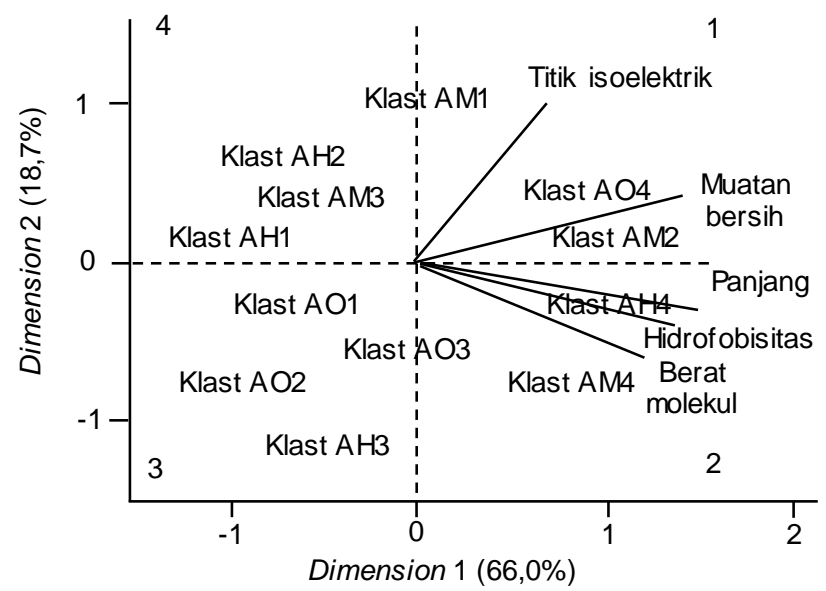

Keterangan: $\mathrm{AH} 1, \mathrm{AH} 2, \mathrm{AH} 3, \mathrm{AH} 4$ : Antihipertensi klaster 1 , klaster 2, klaster 3, dan klaster 4; AO1, AO2, AO3, AO4 : Antioksidan klaster 1, klaster 2, klaster 3 dan klaster 4; AM1, AM2, AM3, AM4 : Antimikroba klaster 1, klaster 2, klaster 3 dan klaster 4

Gambar 2a. Biplot dari klastering penciri dan sifat fungsional peptida bioaktif dengan 4 klaster

Pada biplotting dengan 4 klaster, klaster $\mathrm{AH} 1$ (antihipertensi dengan jumlah anggota terbanyak) berada di garis pembatas kuadran 3 dan 4, berdekatan dengan klaster AO1 (antioksidan dengan jumlah anggota terbanyak) yang berada di kuadran 3 sebelah atas. Sedangkan biplotting dengan 3 klaster, posisi klaster $\mathrm{AH} 1$ dan $\mathrm{AO} 1$ berada pada kuadran yang sama yaitu kuadran 3. Panjang sekuens, berat molekul dan titik isoelektrik peptida antihipertensi dan antioksidan yang konsisten berdekatan pada Tabel 3a dan 3b yang memicu kedekatan kedua sifat fungsional peptida tersebut.

Sebagaimana tampak pada Tabel 3a, nilai centroid panjang sekuens, berat molekul dan titik isoelektrik pada biplotting dengan 4 klaster pada $\mathrm{AH} 1$ dan AO1 adalah masing-masing 3,4 dan 6,7; 404,7 dan 744,2; serta 5,7 dan 5,7. Sedangkan pada Tabel $3 \mathrm{~b}$, nilai centroid panjang sekuens, berat molekul dan titik isoelektrik pada $\mathrm{AH} 1$ dan $\mathrm{AO} 1$ adalah masing-masing 3,8 dan 6,$3 ; 435,9$ dan 744,2; serta 5,9 dan 5,2 . Dibandingkan dengan kedua sifat fungsional (antihipertensi dan antioksidan), sifat antimikroba cukup mencolok perbedaannya. Posisi AM1 (antimikroba dengan jumlah anggota terbanyak) baik dengan 4 klaster (Gambar 2a) maupun 3 klaster (Gambar 2b) berada di area yang sama yaitu di garis pembatas kuadran 4 dan 1 .

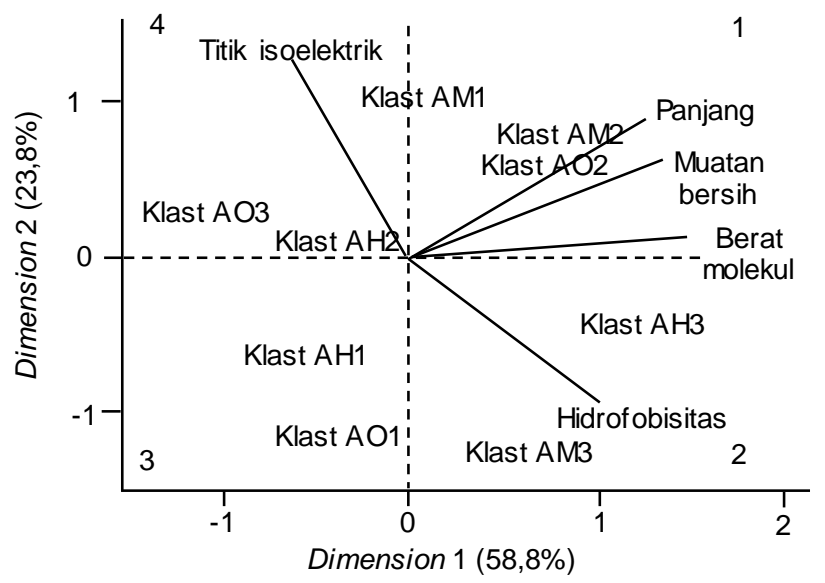

Keterangan: AH1, AH2, AH3: Antihipertensi klaster 1, klaster 2, dan klaster 3; AO1, AO2, AO3: Antioksidan klaster 1, klaster 2, dan klaster 3; AM1, AM2, AM3: Antimikroba klaster 1, klaster 2, dan klaster 3

Gambar 2b. Biplot dari klastering penciri dan sifat fungsional peptida bioaktif dengan 3 klaster

Sebagaimana tampak pada Tabel $3 a$ dan 3b, nilai centroid AM1 (antimikroba dengan jumlah anggota terbanyak) tampak memiliki nilai tertinggi pada setiap pencirinya (panjang, berat molekul, titik isoelektrik dan muatan bersih), kecuali nilai hidrofobisitasnya. Jika dibandingkan nilai centroid masingmasing penciri terhadap sifat fungsionalnya (antihipertensi, antioksidan dan antimikroba) pada jumlah anggotanya terbanyak (pada Tabel 3a) berdasarkan panjang adalah $\mathrm{AH} 1<\mathrm{AO} 1<\mathrm{AM} 1$; berat molekul adalah $\mathrm{AH} 1<\mathrm{AO} 1<\mathrm{AM} 1$; titik isoelektrik adalah $\mathrm{AH} 1=\mathrm{AO} 1<\mathrm{AM} 1$; muatan bersih adalah $\mathrm{AH} 1=\mathrm{AO} 1<$ AM1; dan hidrofobisitas adalah AH1<AO1>AM1. Hal ini mengilustrasikan bahwa sifat antihipertensi dan antioksidan memiliki lebih banyak kemiripan dibandingkan dengan sifat antimikroba. Korelasi penciri sifat fungsional peptida bioaktif yang terdiri atas panjang, berat molekul, titik isoelektrik, muatan bersih dan hidrofobisitas dapat dilihat berdasarkan sudut yang dibentuk vektor penciri tersebut (Mattjik dan Sumertajaya, 2011). 
Tabel 3a. Jumlah anggota klaster dan nilai centroid pada klastering 4 klaster berdasarkan sifat pencirinya

\begin{tabular}{|c|c|c|c|c|c|c|c|c|c|c|}
\hline & \multicolumn{2}{|c|}{ Panjang } & \multicolumn{2}{|c|}{ Berat Molekul } & \multicolumn{2}{|c|}{ Titik Isoelektrik } & \multicolumn{2}{|c|}{ Muatan Bersih } & \multicolumn{2}{|c|}{ Hidrofobisitas } \\
\hline & $\begin{array}{c}\text { Jumlah } \\
\text { Anggota } \\
\text { Klaster }\end{array}$ & Centroid & $\begin{array}{c}\text { Jumlah } \\
\text { Anggota } \\
\text { Klaster }\end{array}$ & Centroid & $\begin{array}{l}\text { Jumlah } \\
\text { Anggota } \\
\text { Klaster }\end{array}$ & Centroid & $\begin{array}{l}\text { Jumlah } \\
\text { Aggota } \\
\text { Klaster }\end{array}$ & Centroid & $\begin{array}{l}\text { Jumlah } \\
\text { Anggota } \\
\text { Klaster }\end{array}$ & Centroid \\
\hline Klaster1 AH & 60 & $3,4 \pm 1,3$ & 59 & $404,7 \pm 153,0$ & 73 & $5,7 \pm 0,5$ & 85 & $0,0 \pm 0,0$ & 58 & $6,5 \pm 1,3$ \\
\hline Klaster2 AH & 39 & $7,4 \pm 1,1$ & 45 & $863,8 \pm 152,3$ & 34 & $10,4 \pm 0,7$ & 22 & $1,0 \pm 0,0$ & 39 & $9,9 \pm 1,0$ \\
\hline Klaster 3 AH & 24 & $12,4 \pm 2,2$ & 19 & $1487,8 \pm 222,4$ & 15 & $3,7 \pm 0,5$ & 16 & $-1,3 \pm 0,4$ & 23 & $12,9 \pm 1,0$ \\
\hline Klaster 4 AH & 12 & $20,7 \pm 3,8$ & 12 & $2331,1 \pm 406,5$ & 13 & $7,9 \pm 0,4$ & 12 & $2,4 \pm 0,5$ & 15 & $20,1 \pm 2,7$ \\
\hline Klaster 1 AO & 10 & $6,7 \pm 1,7$ & 11 & $744,2 \pm 199,8$ & 12 & $5,7 \pm 0,5$ & 12 & $0,0 \pm 0,3$ & 8 & $13,9 \pm 1,1$ \\
\hline Klaster $2 \mathrm{AO}$ & 6 & $2,5 \pm 0,8$ & 5 & $282,7 \pm 32,2$ & 5 & $4,0 \pm 0,7$ & 7 & $-1,0 \pm 0,4$ & 6 & $6,3 \pm 1,1$ \\
\hline Klaste & 4 & $18,0 \pm 1,4$ & 3 & $2152,1 \pm 113,9$ & 4 & $8,2 \pm 0,9$ & 2 & $-2,0 \pm 2,3$ & 4 & $10,1 \pm 0,5$ \\
\hline Klaster 4 AO & 2 & $15,5 \pm 0,7$ & 3 & $1731,9 \pm 71,6$ & 1 & $11,5 \pm 0,0$ & 1 & $2,0 \pm 0,0$ & 4 & $17,4 \pm 0,5$ \\
\hline Klaster 1 AM & 10 & $10,2 \pm 2,1$ & 9 & $1034,8 \pm 176,0$ & 9 & $11,5 \pm 0,6$ & 12 & $1,0 \pm 0,0$ & 11 & $11,2 \pm 1,6$ \\
\hline Klaster 2 AM & 6 & $18,3 \pm 1,0$ & 7 & $1839,2 \pm 143,2$ & 6 & $10,3 \pm 0,2$ & 7 & $2,4 \pm 0,8$ & 6 & $17,8 \pm 1,3$ \\
\hline Klaster 3 AM & 5 & $14,4 \pm 1,5$ & 5 & $1401,0 \pm 124,0$ & 5 & $9,9 \pm 0,1$ & 5 & $-0,3 \pm 0,7$ & 6 & $6,6 \pm 1,8$ \\
\hline Klaster 4 AM & 4 & $23,0 \pm 3,1$ & 4 & $2297,1 \pm 113,8$ & 5 & $6,8 \pm 1,9$ & 1 & $3,5 \pm 0,0$ & 2 & $22,4 \pm 3,7$ \\
\hline
\end{tabular}

Keterangan: Klastering dilakukan dengan metode simple K Means. Nilai centroid adalah rerata nilai anggota kaster pada setiap kaster di kelompok sifat fungsionalnya. $\mathrm{AH}=$ Antihipertensi; $\mathrm{AO}=$ Antioksidan; $\mathrm{AM}=\mathrm{Antimikroba}$

Tabel 3b. Jumlah anggota klaster dan nilai centroid pada klastering 3 klaster berdasarkan sifat pencirinya

\begin{tabular}{|c|c|c|c|c|c|c|c|c|c|c|}
\hline & \multicolumn{2}{|c|}{ Panjang } & \multicolumn{2}{|c|}{ Berat Molekul } & \multicolumn{2}{|c|}{ Titik Isoelektrik } & \multicolumn{2}{|c|}{ Muatan Bersih } & \multicolumn{2}{|c|}{ Hidrofobisitas } \\
\hline & $\begin{array}{l}\text { Jumlah } \\
\text { Aggota } \\
\text { Klaster }\end{array}$ & Centroid & $\begin{array}{c}\text { Jumlah } \\
\text { Anggota } \\
\text { Klaster }\end{array}$ & Centroid & $\begin{array}{c}\text { Jumlah } \\
\text { Anggota } \\
\text { Klaster }\end{array}$ & Centroid & $\begin{array}{l}\text { Jumlah } \\
\text { Aggota } \\
\text { Klaster }\end{array}$ & Centroid & $\begin{array}{l}\text { Jumlah } \\
\text { Aggota } \\
\text { Klaster }\end{array}$ & Centroid \\
\hline Klaster $1 \mathrm{AH}$ & 71 & $3,8 \pm 1,5$ & 67 & $435,9 \pm 167,2$ & 80 & $5,9 \pm 0,7$ & 107 & $0,2 \pm 0,4$ & 69 & $6,8 \pm 1,4$ \\
\hline Klaster $2 \mathrm{AH}$ & 44 & $9,1 \pm 1,9$ & 46 & $980,6 \pm 200,0$ & 40 & $10,0 \pm 1,0$ & 16 & $-1,3 \pm 0,4$ & 50 & $11,5 \pm 1,5$ \\
\hline Klaster $3 \mathrm{AH}$ & 20 & $18,4 \pm 4,1$ & 22 & $2030,6 \pm 451,0$ & 15 & $3,7 \pm 0,5$ & 12 & $2,3 \pm 0,5$ & 16 & $19,8 \pm 2,8$ \\
\hline Klaster $1 \mathrm{AO}$ & 10 & $6,3 \pm 1,7$ & 11 & $744,2 \pm 199,8$ & 17 & $5,2 \pm 0,9$ & 18 & $-0,3 \pm 0,5$ & 10 & $16,1 \pm 2,3$ \\
\hline Klaster $2 \mathrm{AO}$ & 6 & $17,2 \pm 1,7$ & 6 & $1942,0 \pm 243,3$ & 4 & $8,2 \pm 0,9$ & 2 & $1,5 \pm 0,7$ & 6 & $10,9 \pm 1,4$ \\
\hline Klaster $3 \mathrm{AO}$ & 6 & $2,5 \pm 0,8$ & 5 & $282,7 \pm 32,2$ & 1 & $11,5 \pm 0,0$ & 2 & $-2,0 \pm 0,0$ & 6 & $6,3 \pm 1,1$ \\
\hline Klaster $1 \mathrm{AM}$ & 10 & $19,6 \pm 2,5$ & 13 & $1132,5 \pm 212,3$ & 12 & $10,1 \pm 0,2$ & 14 & $1,0 \pm 0,0$ & 14 & $8,8 \pm 2,3$ \\
\hline Klaster 2 AM & 8 & $13,5 \pm 1,7$ & 8 & $1808,8 \pm 158,0$ & 9 & $11,5 \pm 0,6$ & 7 & $2,4 \pm 0,8$ & 9 & $16,3 \pm 1,6$ \\
\hline Klaster 3 AM & 7 & $9,4 \pm 2,1$ & 4 & $2297,1 \pm 113,8$ & 4 & $6,0 \pm 0,9$ & 4 & $-0,3 \pm 0,5$ & 2 & $22,3 \pm 1,2$ \\
\hline
\end{tabular}

Keterangan: Klastering dilakukan dengan metode simple K Means. Nilai centroid adalah rerata nilai anggota kaster pada setiap kaster di kelompok sifat fungsionalnya. $\mathrm{AH}=$ Antihipertensi; $\mathrm{AO}=$ Antioksidan; $\mathrm{AM}=$ Antimikroba

\section{KESIMPULAN}

Kehadiran suatu asam amino tidak cukup dalam mencirikan suatu sifat fungsional pada peptida bioaktif, seperti kehadiran residu asam amino gugus aromatik dan alifatik pada peptida yang memiliki sifat antihipertensi dan antioksidan serta residu asam amino bergugus kation pada peptida yang memiliki sifat antimikroba. Penciri yang dibangkitkan dari sekuens peptida biokatif meliputi panjang sekuens, berat molekul, titik isoelektrik, muatan bersih dan hidrofobisitas secara simultan digunakan untuk mencirikan sifat fungsional peptida bioaktif. Peptida bioaktif dengan sifat antihipertensi dan antioksidan memiliki beberapa kemiripan, sedangkan sifat antimikroba cukup besar perbedaannya terhadap sifat antihipertensi dan antioksidan. Panjang sekuens, berat molekul dan titik isoelektrik pada peptida antihipertensi dan antioksidan memiliki nilai yang sangat berdekatan sehingga menjadi penciri kesamaan sifat kedua sifat fungsional tersebut. Peptida antimikroba memiliki nilai yang tertinggi dibandingkan peptida antihipertensi dan antioksidan dalam hal penciri panjang sekuens, berat molekul, titik isoelektrik dan muatan bersih, kecuali hidrofobisitas. Hasil penelitian ini diharapkan dapat mengembangakan studi tentang peptida bioaktif dan menjadi alternatif penentuan sifat fungsional peptida bioaktif, khususnya anti- hipertensi, antioksidan dan antimikroba, melalui pendekatan sifat fisik dan kimianya. Untuk penelitian lanjutan, telaah secara in vitro terhadap kandungan peptida bioaktif dan menguji bioaktifitasnya pada bahan pangan dan produk fermentasi asli Indonesia penting untuk dilakukan.

\section{UCAPAN TERIMAKASIH}

Ucapan terima kasih penulis sampaikan kepada Kemenristek Dikti yang telah membiayai penelitian ini dalam skema Penelitian Unggulan Dasar Simlitabmas tahun 2017 dengan nomor kontrak 1388/ IT3.11/PN/2017.

\section{DAFTAR PUSTAKA}

Abdelhadi O, Nasri R, Jridi M, Mora L, Toledo, MEO, Aristoy MC, Amara IB, Toldra F, Nasri M. 2017. In silico analysis and antihypertensive effect of ACE-inhibitory peptides from smooth-hound viscera protein hydrolysate: Enzyme-peptide interaction study using molecular docking simulation. Process Biochem 58: 145-159. DOI: 10. 1016/j.procbio.2017.04.032. 
Amadou I, Le GW, Amza T, Sun J, Shi YH. 2013. Purification and characterization of foxtail milletderived peptides with antioxidant and antimicrobial activities. Food Res Int 51: 422-428. DOI: 10.1016/j.foodres.2012.12.045.

Capriotti AL, Caruso G, Cavaliere C, Saperi R, Ventura S, Chiozzi RZ, Lagana A. 2015. Identification of potential bioactive peptides generated by simulated gastrointestinal digestion of soybean seeds and soy milk proteins. J Food Compos Anal 44: 205-213. DOI: 10.1016/j.jfca. 2015.08.007.

Carrasco-Castilla J, Hernández-Álvarez AJ, Jiménez-Martínez C, Jacinto-Hernández $C$, Alaiz $M$, Girón-Calle J. 2012. Antioxidant and metal chelating activities of Phaseolus vulgaris $\mathrm{L}$. var. Jamapa protein isolates, phaseolin and lectin hydrolysates. Food Chem 131: 1157-1164. DOI: 10.1016/j.foodchem.2011.09.084.

Castro RJS, Sato HH. 2015. Biologically active peptides: Processes for their generation, purification and identification and applications as natural additives in the food and pharmaceutical industries. Food Res Int 74: 185-198. DOI: 10. 1016/j.foodres.2015.05.013.

Coscueta ER, Amorim MM, Voss GB, Nerli BB, Picó GA, Pintado ME. 2015. Bioactive properties of peptides obtained from Argentinian defatted soy flour protein by Corolase PP hydrolysis. Food Chem 198: 36-44. DOI: 10.1016/j.foodchem. 2015.11.068.

Dashper SG, Liu SW, Reynolds EC. 2007. Antimicrobial peptides and their potential as oral therapeutic agents. Int. J Pept Res Ther 13: 505516. DOI: 10.1007/s10989-007-9094-z.

Duan X, Ocen D, Wu F, Li M, Yang N, Xu J. 2014. Purification and characterization of a natural antioxidant peptide from fertilized eggs. Food Res Int 56: 18-24. DOI: 10.1016/j.foodres.20 13.12.016.

Estrada G. 2011. Peptide drawings made easy. http://www.ohr.tulane.edu/news/newwave/0104 11_peptides.cfm?RenderForPrint=1 [15 Januari 2017]. DOI: 10.1016/j.foodres.2013.12.016.

He R, Ju X, Yuan J, Wang L, Girgih AT, Aluko RE. 2012. Antioxidant activities of rapeseed peptides produced by solid state fermentation. Food Res Int 49: 432-438. DOI: 10.1111/j.13652621.2010.02239.x.
Huang S, Chen K N, Chen YP, Hong WS, Chen MJ. 2010. Immunomodulatory properties of the milk whey products obtained by enzymatic and microbial hydrolysis. Int $\mathrm{J}$ Food Sci Tech 45: 1061-1067. DOI: 10.1111/j.1365-2621.2010.02 239.x.

Mattjik AA, Sumertajaya IM. 2011. Sidik Pengubah Ganda dengan menggunakan SAS. 246-270. IPB Press. Bogor.

McClean S, Beggs LB, Welch RW. 2014. Antimicrobial activity of antihypertensive food-derived peptides and selected alanine analogues. Food Chem 146: 443-447. DOI: 10.1016/j.foodchem. 2013.09.094.

Minkiewicz $P$, Dziuba J, Iwaniak A, Dziuba M, Darewicz M. 2008. BIOPEP database and other programs for processing bioactive peptide sequences. J AOAC Int 91: 965-980.

Nagpal R, Behare P, Rana R, Kumar A, Kumar M, Arora S, Morotta F, Jain S, Yadaf H. 2011. Bioactive peptides derived from milk proteins and their health beneficial potentials. Food Funct 2: 18-27. DOI: 10.1039/COFO00016G.

Puchalska P. Garcia MC. Marina ML. 2014. Identification of native angiotensin-1 converting enzyme inhibitory peptides in commercial soybean based infant formulas using HPLC-Q-ToFMS. Food Chem 157: 62-29. DOI: 10.1016/j. foodchem.2014.01.130.

Rai AK. Sanjukta S, Jeyaram K. 2015. Production of Angiotensin I converting enzyme inhibitory (ACE-I) peptides during milk fermentation and its role in treatment of hypertension. Cri Rev Food Sci 57: 2789-2800. DOI: 10.1080/104083 98.2015.1068736.

Ryan JT, Ross RP, Bolton D, Fitzgerald GF, Stanton C. 2011. Bioactive peptides from muscle sources: meat and fish. Nutrients 3: 765-791. DOI: 10.3390/nu3090765.

Sarmadi BH, Ismail A. 2010. Antioxidative peptides from food proteins - a review. Peptides 31: 1949-1956. DOI: 10.1016/j.peptides.2010.06. 020.

Sanjukta S, Rai AK. 2015. Production of bioactive peptides during soybean fermentation and their potential health benefits. Trends Food Sci Tech 50: 1-10. DOI: 10.1016/j.tifs.2016.01.010. 
Tang W, Zhang H, Wang L, Qian H, Qi X 2015. Targeted separation of antibacterial peptide from protein hydrolysate of anchovy cooking wastewater by equilibrium dialysis. Food Chem 168: 115-123. DOI: 10.1016/j.foodchem.2014.0 7.027.

Torres-Llanez MJ, Cordova G, Mendoza H, Garcia HS. 2011. Angiotensin-converting enzyme inhibitory activity in Mexican Fresco cheese. J Dairy Sci 94: 3794-3800. DOI: 10.3168/jds. 2011-4237.
Tsai. 2008. ACE-inhibitory peptides identified from the muscle protein hydrolysate of hard clam (Meretrix lusoria). Process Biochem 43: 743747. DOI: 10.1016/j.procbio.2008.02.019.

Wijesekara I, Qian Z, Ryu B, Ngo D, Kim S. 2011. Purification and identification of antihypertensive peptides from seaweed pipefish (Syngnathus schlegeli) muscle protein hydrolysate. Food Res Int 44: 703-707. DOI: 10.1016/ j.foodres.2010.12.022. 